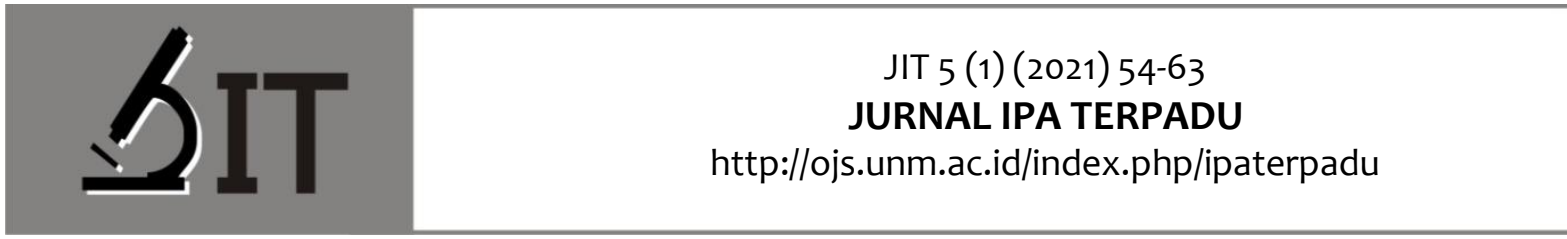

p-ISSN : 2597-8977

e-ISSN : 2597-8985

\section{KAJIAN ETNOSAINS PROSES PRODUKSI GARAM AMED SEBAGAI PENDUKUNG MATERI PEMBELAJARAN IPA SMP}

Ni Luh Putu Oktiyana Rista Ayuni Universitas Pendidikan Ganesha

I Nyoman Suardana Universitas Pendidikan Ganesha

Luh Mitha Priyanka*) Universitas Pendidikan Ganesha
*) Correspondence Author: luh.mitha@undiksha.ac.id
Abstrak: Penelitian ini bertujuan untuk mengkaji proses produksi Garam Amed dan menganalisis kajian etnosains yang terdapat dalam proses produksi Garam Amed pada materi IPA SMP. Penelitian ini menggunakan pendekatan kualitatif dengan jenis penelitian etnosains. Sumber data dipilih secara purposive. Subjek dalam penelitian ini adalah Ketua MPIG Garam Amed Bali, Petani Garam Amed, dan Guru IPA SMPN 2 Amlapura. Data primer dan sekunder diperoleh melalui teknik observasi, wawancara, dan dokumentasi. Teknik analisis data yang digunakan adalah analisis sebelum lapangan, analisis model Miles \& Hubarman, triangulasi sumber dan teknik. Hasil penelitian menunjukkan bahwa proses produksi Garam Amed terdiri atas delapan tahap utama. Kajian etnosains dalam proses produksi Garam Amed terdapat pada materi IPA SMP kelas 7 dan 8 khusunya pada Materi Klasifikasi Makhluk Hidup, Zat Aditif dan Adiktif, Sistem Pencernaan Manusia, Klasifikasi Materi dan Perubahannya, serta Suhu dan Perubahannya. Dengan dianalisisnya konsep-konsep IPA dalam proses produksi Garam Amed diharapkan siswa lebih mudah memahami konsep mengenai kompetensi dasar yang berkaitan dengan garam dan proses produksinya karena sumber belajar baru yang diterima siswa bersifat kontekstual yang dapat dijumpai dalam kehidupan sehari-hari.

Kata Kunci: Garam Amed, Etnosains, Materi IPA.

Abstract: This study aims to examine the production process of Amed Salt and analyze the ethnoscientific studies contained in the Amed Salt production process in junior high school science material. This study uses a qualitative approach with the type of ethnoscience research. The data sources were selected purposively. The subjects in this study were the Chairperson of MPIG Garam Amed Bali, Amed Salt Farmers, and Science Teachers at SMPN 2 Amlapura. Primary and secondary data were obtained through observation, interview, and documentation techniques. The data analysis techniques used were pre-field analysis, Miles \& Hubarman model analysis, source and technique triangulation. The results showed that the Amed Salt production process consisted of eight main stages. Ethnoscience studies in the Amed Salt production process are found in junior high school science materials, especially on Classification of Living Things, Additives and Addictive Substances, Human Digestive System, Classification of Matter and Its Changes, and Temperature and Changes.

Keyword: Amed Salt, Ethnoscience, Science Material. 


\section{PENDAHULUAN}

Ilmu Pengetahuan Alam (IPA) merupakan cabang pengetahuan yang mempelajari tentang alam semesta yang bermula dari fenomena alam. Trianto (2010) mengemukakan bahwa IPA merupakan ilmu pengetahuan yang mempelajari tentang suatu gejala melalui serangkaian proses yang disebut dengan proses ilmiah, yang dibangun berdasarkan pada sikap ilmiah dan hasilnya berupa produk ilmiah yang tersusun atas tiga komponen penting diantaranya berupa konsep, prinsip, serta teori yang berlaku secara general. Kegiatan pembelajaran IPA semestinya bersifat bermakna bagi siswa atau dapat dikatakan bersifat kontekstual, artinya terdapat keselarasan antara sumber belajar yang diperoleh siswa baik berupa teori, konsep, maupun hukum dengan pengaplikasiannya, sehingga siswa mampu mengasosiasikan fenomena, pengalaman, serta faktafakta baru ke dalam struktur pengetahuannya. Pernyataan ini didukung oleh Puspasari (2019) yang menyatakan bahwa pembelajaran yang bersifat kontekstual merupakan jembatan penghubung antara konsep yang dipelajari siswa dengan penerapannya di kehidupan nyata yang berguna untuk mengatasi kesulitan siswa dalam menyerap pelajaran yang bersifat abstrak dengan menyediakan pengalaman belajar yang melibatkan siswa secara kompleks sesuai dengan kenyataan yang disaksikannya (real).

Salah satu upaya yang dapat dilakukan untuk menciptakan kegiatan pembelajaran yang bersifat kontekstual adalah dengan melibatkan kearifan lokal yang terdapat di masyarakat. Menurut Sumarni (2018) kearifan okal merupakan bentuk pengetahuan lokal yang telah menyatu dengan sistem kepercayaan, norma, dan budaya yang diekspresikan dalam bentuk tradisi yang dianut dalam jangka waktu yang lama. Tujuan dilakukannya kegiatan pembelajaran dengan melibatkan kearifan lokal adalah untuk memudahkan siswa dalam memahami materi pembelajaran karena kearifan lokal tersebut berada di lingkungan yang dekat dengan siswa. Sudarmin (2014) berpendapat bahwa kearifan lokal sebagai jatidiri bangsa dan, karakter dan adat istiadat budaya lokal yang dilibatkan dalam proses pembelajaran ilmu sains disebut dengan pembelajaran berpendekatan etnosains. Etnosains merupakan sebuah ilmu pengetahuan yang dimiliki oleh masyarakat atau suku bangsa pada suatu daerah yang diperoleh dengan menggunakan metode serta prosedur tertentu yang merupakan bagian dari tradisi masyarakat atau suku bangsa setempat dan kebenarannya dapat diuji secara empiris (Sudarmin, 2014).

Berdasarkan hasil observasi yang dilakukan di SMP Negeri 2 Amlapura ditemukan bahwa siswa mengalami kesulitan belajar karena kegiatan pembelajaran IPA yang dilakukan cenderung berorientasi pada buku teks dan kurangnya eksplorasi terhadap lingkungan sekitar yang berpotensi menjadi sumber belajar baru bagi siswa. Permasalahan serupa dijumpai oleh Hadi (2019) bahwa pembelajaran IPA hanya bersifat teoretis dan kurang diintegrasikan dalam kehidupan siswa sehingga pembelajaran akan kurang bermakna. Hal ini dikarenakan keberagaman budaya belum banyak dikembangkan sebagai sumber menyatakan bahwa banyak guru belum memanfaatkan budaya daerah sebagai bahan ajar dalam pembelajaran IPA. Hasil wawancara yang dilakukan pada Guru IPA di SMP Negeri 2 Amlapura yang menyatakan bahwa guru di sekolah tersebut mengalami beberapa kendala dalam mengembangkan bahan ajar berbasis kearifan lokal diantaranya adalah kendala waktu, uang, dan rendahnya pengetahuan guru tentang kearifan lokal yang ada di daerah setempat.

Karangasem merupakan salah satu kabupaten yang ada di Pulau Bali dengan berbagai warisan kebudayaan di masing-masing daerahnya. Salah satu warisan kebudayaan tersebut adalah Garam Amed. Garam Amed yang diperkirakan telah ada sejak sebelum tahun 1.500 Saka atau 1.578 Masehi (MPIG, 2015). Proses produksi Garam Amed dilakukan dengan menggunakan teknik khas yang diperoleh secara turun temurun dari nenek moyang masyarakat Desa Amed sejak sebelum masa Kerajaan Karangasem. Secara tidak langsung proses pembuatan Garam Amed telah melibatkan konsep sains dapat digunakan sebagai tambahan materi yang bersifat kontekstual pada pelajaran IPA oleh guru dan siswa di sekitar lingkungan masyarakat pembuat garam, sehingga 
diharapkan konsep-konsep penting dalam pembelajaran IPA dapat dipahami dengan mudah oleh siswa. Tujuan penelitian ini adalah untuk mengkaji proses produksi Garam Amed dan menganalisis kajian etnosains yang terdapat dalam proses produksi Garam Amed pada materi IPA SMP.

\section{METODE}

Penelitian ini merupakan penelitian kualitatif dengan jenis penelitian etnosains. Penelitian ini dilakukan di Banjar Dinas Amed, Desa Purwakerthi, Kecamatan Abang, Kabupaten Karangasem, Provinsi Bali. Sampel dalam penelitian ini dipilih menggunakan teknik purposive sampling. Subjek yang dilibatkan dalam penelitian adalah Ketua MPIG Garam Amed Bali, 3 orang Petani Garam Amed, serta Guru IPA SMP Negeri 2 Amlapura. Objek dalam penelitian ini adalah proses produksi Garam Amed serta kajian etnosains dalam proses produksi Garam Amed pada materi pembelajaran IPA SMP kelas VII dan VIII. Seluruh data penelitian diperoleh menggunakan teknik observasi, wawancara terstruktur, dan dokumentasi. Teknik analisis yang digunakan untuk mengolah data adalah analisis sebelum lapangan. Analisis ini dilakukan terhadap data hasil studi pendahuluan atau data sekunder yang digunakan sebagai fokus penelitian. Fokus penelitian akan berkembang seiring dengan pengumpulan data (Sugiyono, 2017a). Teknik analisis selanjutnya adalah analisis data di lapangan model Miles \& Huberman yang terdiri dari tiga alur kegiatan yang terjadi secara bersamaan yaitu: reduksi data, penyajian data, penarikan kesimpulan/verifikasi. Miles \& Huberman dalam Sugiyono (2017a) mengemukakan bahwa aktivitas dalam analisis data kualitatif dilakukan secara interaktif dan berlangsung secara terus-menerus, hingga data yang diperoleh sudah jenuh. Teknik analisis selanjutnya adalah triangulasi sumber yang dilakukan untuk menguji kredibilitas data dengan cara mengecek data yang diperoleh melalui beberapa sumber (Sugiyono, 2017a). Teknik analisis yang dilakukan selanjutnya adalah triangulasi teknik yang dilakukan dengan cara mengecek data kepada sumber yang sama dengan teknik yang berbeda (Sugiyono, 2017b).

\section{HASIL DAN PEMBAHASAN}

\section{Hasil}

\section{a. Proses Produksi Garam Amed}

Berdasarkan hasil observasi, wawancara, dan dokumentasi yang telah dilakukan, diperoleh data mengenai proses produksi Garam Amed. Proses produksi Garam Amed diawali dengan persiapan pesasahan atau petak penggaraman. Petani Garam Amed mengawali proses produksi garam dengan menyirami salah satu dari empat pesasahan menggunakan air laut. Tujuan dilakukannya hal tersebut adalah untuk menambah zat garam yang ada di dalam tanah sari, agar nantinya garam yang dihasilkan lebih gurih. Air laut yang telah dituangkan di tanah sari kemudian diratakan dengan cara diaduk-aduk menggunakan bangkrak. Kegiatan ini dilakukan pada pagi hari, kemudian tanah sari di petak tersebut ditunggu kering. Siang harinya tanah yang berada di petak tersebut telah kering, kemudian dinaikkan ke atas tinjungan menggunakan angkup yang saat ini telah digantinya dengan sekop. Tanah sari yang sudah berada di atas tinjungan kemudian diratakan dan dipadatkan dengan cara diinjak-injak. Setelah permukaannya rata dan padat, kemudian tinjungan disiram dengan air laut menggunakan pompa air hingga penuh. Tidak terdapat kritreria khusus pada air laut yang digunakan, selama air laut yang digunakan berasal dari laut Amed. Air lama-kelamaan akan menetes dan terkumpul di penyusuan atau di tempat penampungan. Proses penyaringan ini berlangsung selama semalaman. Esok harinya air di tinjungan telah surut dan seluruhnya terkumpul di penyusuan. Yeh nyah kemudian diambil menggunakan sibuh. Terdapat dua jenis sibuh berdasarkan ukurannya, yaitu sibuh dengan ukuran besar dan kecil. Masing-masing sibuh 
memiliki fungsinya tersendiri, sibuh yang berukuran besar digunakan saat cuaca bagus, tidak berawan, dan sinar matahari bersinar cerah, sedangkan sibuh yang berukuran kecil digunakan saat cuaca kurang bagus, kondisi langit berawan, dan terik sinar matahari redup tertutup oleh awan. Yeh nyah yang telah ditimba menggunakan sibuh kemudian dituangkan ke atas palungan untuk selanjutnya dijemur. Garam terbentuk pada hari pertama penjemuran, namun garam yang dihasilkan masih tipis dan sangat basah. Garam yang baik akan dihasilkan di hari keempat, kemudian dipanen. Kegiatan memanen garam dilakukan menggunakan pengerikan lalu dikumpulkan pada wadah yang disebut dengan gangan. Setelah dipanen, garam yang telah diwadahi gangan kemudian ditiriskan dengan diletakkan di pinggiran palungan selama beberapa hari. Garam yang sudah tiris, kemudian dibawa ke rumah produksi untuk selanjutnya disortir dan dikemas. Selain garam, Petani Garam Amed juga memproduksi Bunga Garam Amed. Proses produksi Bunga Garam Amed hampir sama dengan proses produksi Garam Amed, hanya saja terdapat sedikit perbedaan yang terletak pada waktu pemanenan. Panen garam dilakukan pada saat sore hari, sedangkan Bunga Garam Amed dipanen pada siang hari, karena apabila Bunga Garam Amed dipanen pada sore hari, maka Bunga Garam Amed tersebut akan berubah menjadi garam biasa. Garam dan Bunga Garam Amed dipanen bersamaan di hari ke empat, namun keberadaan Bunga Garam Amed tidak selalu ada, hal ini dipengaruhi oleh cuaca. Garam dan Bunga Garam Amed yang dihasilkan kemudian dikemas di rumah produksi. Garam dan Bunga Garam Amed harus melalui tahap sorti yang dilakukan secara manual, dengan memisahkan pengotor garam. Kotoran yang dijumpai biasanya adalah serat-serat batang pohon kelapa.

\section{b. Penggalian Pengetahuan Umum Mengenai Garam dan Proses Produksianya}

Proses penggalian pengetahuan umum mengenai garam dan proses produksinya dilakukan dengan teknik wawancara. Wawancara dilakuakan dengan Ketua MPIG Garam Amed Bali, Petani Garam Amed, dan Guru IPA SMP Negeri 2 Amlapura. Pertanyaan-pertanyaan yang diajukan kepada seluruh narasumber pada wawancara ini adalah sama. Jumlah seluruh pertanyaan mengenai garam dan proses produksinya terdiri atas tujuh butir. Berikut merupakan hasil penggalian pengetahuan umum mengenai garam dan proses produksinya yang ditunjukkan oleh Tabel 1.

Tabel 1. Penggalian Pengetahuan Umum Mengenai Garam dan Proses Produksinya

\begin{tabular}{|c|c|c|c|c|}
\hline No & Pertanyaan & $\begin{array}{c}\text { Ketua MPIG Garam } \\
\text { Amed Bali }\end{array}$ & Petani Garam Amed & Guru IPA \\
\hline 1 & $\begin{array}{l}\text { Apakah yang } \\
\text { dimaksud dengan } \\
\text { garam menurut } \\
\text { Bapak/lbu? }\end{array}$ & $\begin{array}{l}\text { Butiran kristal yang } \\
\text { asin yang sangat } \\
\text { dibutuhkan oleh tubuh } \\
\text { manusia yang } \\
\text { mengandung } \\
\text { magnesium, } \mathrm{NaCl} \text {, } \\
\text { kalsium. }\end{array}$ & $\begin{array}{l}\text { Bahan masakan untuk } \\
\text { menambah rasa asin } \\
\text { pada makanan yang } \\
\text { berbentuk butiran. }\end{array}$ & $\begin{array}{l}\text { Salah satu senyawa ionik } \\
\text { yang terdiri atas ion-ion } \\
\mathrm{Na}^{+} \text {dan } \mathrm{Cl}^{-} \text {. Garam } \\
\text { bermuatan netral yang } \\
\text { terbentuk dari reaksi } \\
\text { asam dan basa. } \\
\text { Konsep sains: } \\
\text { lon, unsur, senyawa, dan } \\
\text { campuran }\end{array}$ \\
\hline 2 & $\begin{array}{l}\text { Apa fungsi garam } \\
\text { dalam kehidupan } \\
\text { sehari-hari? }\end{array}$ & $\begin{array}{l}\text { Memasak, } \\
\text { mengawetkan } \\
\text { makanan. }\end{array}$ & $\begin{array}{l}\text { Memasak, } \\
\text { mengawetkan } \\
\text { makanan. }\end{array}$ & $\begin{array}{l}\text { Umunya digunakan untuk } \\
\text { keperluan konsumsi. } \\
\text { Berdasarkan jenisnya, } \\
\text { selain garam konsumsi } \\
\text { terdapat juga garam } \\
\text { untuk kebutuhan industri. }\end{array}$ \\
\hline
\end{tabular}




\begin{tabular}{|c|c|c|c|c|}
\hline No & Pertanyaan & $\begin{array}{l}\text { Ketua MPIG Garam } \\
\text { Amed Bali }\end{array}$ & Petani Garam Amed & Guru IPA \\
\hline & & & & $\begin{array}{l}\text { Konsep sains: } \\
\text { Zat aditif alami dan buatan }\end{array}$ \\
\hline 3 & $\begin{array}{l}\text { Apa manfaat garam } \\
\text { bagi Kesehatan } \\
\text { tubuh manusia? }\end{array}$ & $\begin{array}{l}\text { Mmencegah penyakit } \\
\text { gondok dan sebagai } \\
\text { campuran dalam } \\
\text { larutan oralit. }\end{array}$ & $\begin{array}{l}\text { Campuran } \\
\text { larutan oralit. }\end{array}$ & $\begin{array}{l}\text { Penyeimbang cairan } \\
\text { tubuh, mencegah tekanan } \\
\text { darah rendah, mencegah } \\
\text { penyakit gondok akibat } \\
\text { kekurangan yodium. } \\
\text { Konsep sains: } \\
\text { Sistem pencernaan }\end{array}$ \\
\hline 4 & $\begin{array}{l}\text { Apa bahan baku } \\
\text { pembuatan garam? }\end{array}$ & Air laut. & Air laut. & $\begin{array}{l}\text { Air laut dengan cara } \\
\text { diuapkan dengan bantuan } \\
\text { sinar matahari. } \\
\text { Konsep sains: } \\
\text { Perubahan wujud secara } \\
\text { fisika }\end{array}$ \\
\hline 5 & $\begin{array}{l}\text { Dalam pembuatan } \\
\text { garam, sumber } \\
\text { energi apa yang } \\
\text { paling dibutuhkan? }\end{array}$ & Energi matahari. & Energi matahari. & $\begin{array}{l}\text { Energi panas dari } \\
\text { matahari. } \\
\text { Konsep sains: } \\
\text { Perpindahan kalor }\end{array}$ \\
\hline 6 & $\begin{array}{l}\text { Apa tujuan dilakukan } \\
\text { penyaringan atau } \\
\text { filtrasi } \\
\text { menggunakan } \\
\text { tinjungan? }\end{array}$ & $\begin{array}{l}\text { Untuk menyaring } \\
\text { benda pengotor yang } \\
\text { terdapat di air laut. }\end{array}$ & $\begin{array}{l}\text { Untuk menyaring } \\
\text { benda pengotor yang } \\
\text { terdapat di air laut. }\end{array}$ & $\begin{array}{l}\text { Untuk memisahkan } \\
\text { campuran antara zat } \\
\text { terlarut dapat berupa } \\
\text { pengotor yang sifatnya } \\
\text { solid atau padat dengan } \\
\text { zat pelarut (air laut) } \\
\text { dengan menggunakan } \\
\text { media saring yaitu } \\
\text { tinjungan. } \\
\text { Konsep sains: } \\
\text { Pemisahan campuran }\end{array}$ \\
\hline 7 & $\begin{array}{l}\text { Tahap atau proses } \\
\text { apa yang } \\
\text { menyebabkan } \\
\text { terbentuknya kristal } \\
\text { garam? }\end{array}$ & Tahap penjemuran. & Tahap penjemuran. & $\begin{array}{l}\text { Tahap penjemuran. } \\
\text { Konsep sains: } \\
\text { Pemisahan campuran }\end{array}$ \\
\hline 8 & $\begin{array}{lr}\text { Mengapa } & \text { pada } \\
\text { tahap atau } & \text { proses } \\
\text { tersebut } & \text { dapat } \\
\text { terbentuk } & \text { kristal } \\
\text { garam? } & \end{array}$ & $\begin{array}{l}\text { Karena air laut akan } \\
\text { menguap terkena } \\
\text { panas matahari, } \\
\text { sehingga tersisa kristal } \\
\text { garam saja. }\end{array}$ & $\begin{array}{l}\text { Karena menguap air } \\
\text { lautnya saking } \\
\text { panasnya saat dijemur }\end{array}$ & $\begin{array}{l}\text { Karena terjadi } \\
\text { kristalisasi } \\
\text { menyebabkan } \\
\text { terbentuknya } \\
\text { bebentuk kristal. } \\
\text { Konsep sains: } \\
\text { Pemisahan campuran }\end{array}$ \\
\hline
\end{tabular}

Apa manfaat garam Kesehatan campuran dalam larutan oralit.

Untuk menyaring enda pengotor yang terdapat di air laut. yang terdapat di air laut. solid atau padat dengan zat pelarut (air laut) dengan menggunakan media saring yaitu tinjungan.

Konsep sains:

Tahap penjemuran.

Konsep sains:

Pemisahan campuran

Karena terjadi peristiwa yang terbentuknya padatan bebentuk kristal.

Konsep sains: 


\section{Pembahasan}

\section{a. Kajian Etnosains dalam Proses Produksi Garam Amed pada Materi Pembelajaran IPA SMP}

Garam Amed merupakan salah satu bentuk kearifan lokal yang terdapat di Kabupaten Karangasem. Proses pembuatannya bersifat turun-temurun yang dipercayai telah ada sejak zaman Kerajaan Karangasem. Terdapat beberapa penerapan konsep sains dalam kegiatan produksinya yang apabila dikaji dapat dijadikan sebagai sumber belajar baru bagi Siswa SMP dalam kegiatan pembelajaran IPA khusunya.

Kegiatan pembelajaran yang melibatkan kearifan lokal yang ada di masyarakat dikatakan sebagai kegiatan pembelajaran berbasis etnosains, sejalan dengan pengertiannya Sumarni (2018) menyatakan bahwa etnosains adalah pengetahuan yang dimiliki oleh kelompok atau individu masyarakat yang dapat direkonstruksi menjadi pengetahuan ilmiah. Pembelajaran berbasis etnosains berperan sebagai sarana untuk menjadikan kegiatan pembelajaran bersifat kontekstual dan bermakna bagi siswa ataupun bagi guru (Sumarni, 2018).

Proses produksi Garam Amed sebelum digunakan sebagai sumber belajar baru bagi siswa harus dikaji terlebih dahulu. Pengkajian dilakukan dengan mencari keterkaitan antara proses produksi Garam Amed dan kompetensi dasar (KD) yang terdapat pada materi IPA. Keterkaitan antara proses produksi Garam Amed dengan kompetensi dasar (KD) dalam materi IPA dijabarkan sebagai Tabel 2 berikut.

Tabel 2. Keterkaitan antara KD pada Mata Pelajaran IPA dan Proses Produksi Garam Amed

\begin{tabular}{|c|c|c|}
\hline No. & Kompetensi Dasar Mata Pelajaran IPA & $\begin{array}{c}\text { Konsep IPA yang Terkandung dalam Proses } \\
\text { Produksi Garam Amed }\end{array}$ \\
\hline 1. & $\begin{array}{l}\text { 3.2 Mengklasifikasi makhluk hidup dan } \\
\text { benda berdasarkan karakteristik yang } \\
\text { diamati. }\end{array}$ & $\begin{array}{l}\text { Proses pengklasifikasian dilakukan pada makhluk } \\
\text { hidup dan benda tak hidup. Keterkaitan terletak } \\
\text { pada pengklasifikasian benda tak hidup yang } \\
\text { meliputi pengklasifikasian berdasarkan unsur, } \\
\text { senyawa, dan campuran. Garam merupakan salah } \\
\text { satu senyawa ionik yang terbentuk dari reaksi } \\
\text { netralisasiantara asam dan basa yang menghasilkan } \\
\text { garam dan air }\end{array}$ \\
\hline
\end{tabular}

2. $\quad 3.3$ Menjelaskan konsep campuran dan zat tunggal (unsur dan senyawa), sifat fisika dan kimia, perubahan fisika dan kimia dalam kehidupan sehari-hari.

a. Tahap filtrasi air laut menggunakan tinjungan yang merupakan salah satu contoh pemisahan campuran

b. Proses terbentuknya garam secara kristalisasi yang merupakan salah satu contoh pemisahan campuran

3. $\quad 3.4$ Menganalisis konsep suhu, pemuaian kalor, perpindahan kalor, dan penerapannya dalam kehidupan sehari-hari termasuk mekanisme menjaga kestabilan suhu tubuh pada manusia.

4. $\quad 3.5$ Menganalisis sistem pencernaan pada manusia dan memahami gangguan yang berhubungan dengan sistem pencernaan,

Terjadi peristiwa perpindahan kalor secara radiasi pada tahap penjemuran yeh nyah di atas palungan

Manfaat garam bagi kesehatan tubuh manusia 


\begin{tabular}{lll}
\hline No. $\quad$ Kompetensi Dasar Mata Pelajaran IPA & $\begin{array}{c}\text { Konsep IPA yang Terkandung dalam Proses } \\
\text { Produksi Garam Amed }\end{array}$ \\
\hline $\begin{array}{l}\text { serta upaya menjaga kesehatan sistem } \\
\text { pencernaan. }\end{array}$ & \\
$\begin{array}{l}\text { 5. } \quad 3.6 \text { Menjelaskan berbagai zat aditif dalam } \\
\text { makanan dan minuman, zat adiktif, serta } \\
\text { dampaknya terhadap kesehatan. }\end{array}$ & $\begin{array}{l}\text { Fungsi garam dalam kehidupan sehari-hari yang } \\
\text { digunakan sebagai bahan masakan dan sarana } \\
\text { pengolahan makanan. Garam termasuk ke dalam } \\
\text { zat aditif alami }\end{array}$ \\
\hline
\end{tabular}

Garam adalah senyawa ionik yang terdiri atas ion positif (kation) dan ion negatif (anion), sehingga dapat membentuk senyawa netral atau tanpa muatan (Hoiriyah, 2019). Garam dapur menurut Suardana (2014) tersusun atas ion $\mathrm{Na}^{+}$dan ion $\mathrm{Cl}^{-}$. Secara fisik, garam merupakan padatan berbentuk kristal berwarna putih yang tersusun atas $80 \%$ senyawa $\mathrm{NaCl}$ yang terdiri atas ion-ion $\mathrm{Na}^{+}$ (natrium) dan $\mathrm{Cl}^{-}$(chlor) (Marihati \& Muryati, 2008), serta senyawa lainnya yang digolongkan sebagai pengotor atau (impuritis) diantaranya adalah oksida besi $\left(\mathrm{Fe}_{2} \mathrm{O}_{3}\right)$, kapur $\left(\mathrm{CaCO}_{3}\right)$, kalsium sulfat $\left(\mathrm{CaSO}_{4}\right)$, magnesium sulfat $\left(\mathrm{MgSO}_{4}\right)$, magnesium klorida $\left(\mathrm{MgCl}_{2}\right)$, dan kalium klorida $(\mathrm{KCl})$. (Efendy, dkk., 2012) Senyawa garam terbentuk dari reaksi netralisasi atau reaksi asam dan basa, pada reaksi tersebut tidak hanya garam yang dihasilkan melainkan juga air (Widodo, dkk., 2014). Materi ini dipelajari siswa kelas VII pada KD 3.2 Mengklasifikasi makhluk hidup dan benda berdasarkan karakteristik yang diamati.

Berkaitan dengan fungsi garam dalam kehidupan sehari-hari, menurut (Efendy, dkk., 2012) garam termasuk ke dalam komoditi penting dalam hal pangan yang digunakan untuk berbagai bahan makanan dan pengolahan makanan, selain itu garam juga merupakan salah satu bahan baku industri. Materi mengenai zat aditif dipelajari siswa SMP kelas VIII pada mata pelajaran IPA khususnya terdapat pada KD 3.6 Menjelaskan berbagai zat aditif dalam makanan dan minuman, zat adiktif, serta dampaknya terhadap kesehatan.

Terdapat berbagai manfaat yang terkandung dalam garam, hal ini karena garam tersusun atas sebagian besar $\mathrm{NaCl}$ yang terdiri atas ion-ion natrium dan chlor. Natrium merupakan salah satu mineral penting bagi tubuh karena tidak dapat terbentuk dengan sendirinya di dalam tubuh manusia (Efendy, dkk., 2012). Natriummemiliki peran penting dalam hal mengatur keseimbangan cairan tubuh khususnya asam dan basa (membentuk larutan Buffer) selain itu juga berfungsi dalam mengatur kelancaran proses kerja otot serta transmisi saraf (Ingot \& Lestari, 2016). Garam konsumsi rumah tangga harus mengandung yodium, kekurangan yodium dapat membahayakan kesehatan yang disebut dengan Gangguan Akibat Kekurangan Yodium (GAKY) yang mencakup keterbelakangan mental permanen, gondok, hingga kegagalan reproduksi (Ingot \& Lestari, 2016). Pemaparan tersebut akan dipelajari siswa SMP kelas VIII pada KD 3.5 Menganalisis sistem pencernaan pada manusia dan memahami gangguan yang berhubungan dengan sistem pencernaan, serta upaya menjaga kesehatan sistem pencernaan.

Bahan baku dari garam adalah air laut, selain itu, garam juga dapat diperoleh melalui penambangan batuan garam (rock salt), sumur garam (brine), dan juga menguapkan air laut dengan bantuan sinar matahari (Rositawati, et al., 2013). Umunya masyarakat Indonesia memperoleh garam dengan cara menguapkan air laut menggunakan bantuan sinar matahari (Ariyanti, 2016). Dalam proses penjemuran air laut dengan mengandalkan sinar matahari terjadi proses evaporasi atau penguapan. Evaporasi atau proses penguapan merupakan bentuk perubahan wujud zat dari wujud cair menjadi gas (Widodo, dkk., 2014). Proses penjemuran tersebut berkaitan dengan KD 3.3 Menjelaskan konsep campuran dan zat tunggal (unsur dan senyawa), sifat fisika dan kimia, perubahan fisika dan kimia dalam kehidupan sehari-hari, yang dipelajari siswa SMP kelas VII. 
Seperti yang telah diketahui bahwa proses produksi garam sangat mengandalkan panas dari sinar matahari untuk menghasilkan kristal garam. Proses penjemuran yang dilakukan oleh petani dengan mengandalkan sinar matahari merupakam salah satu contoh bentuk perpindahan kalor secara radiasi. Radiasi merupakan salah satu bentuk perpindahan kalor tanpa melalui zat perantara atau medium (Widodo, dkk., 2014). Materi ini dipelajari oleh siswa kelas VII pada KD 3.4 Menganalisis konsep suhu, pemuaian kalor, perpindahan kalor, dan penerapannya dalam kehidupan sehari-hari termasuk mekanisme menjaga kestabilan suhu tubuh pada manusia.

Terdapat proses penyaringan air laut dalam memproduksi Garam Amed yang bertujuan untuk membersihkan air laut dari pengotornya sebelum dijemur. Kegiatan penyaringan tersebut dikenal dengan istilah filtrasi. Filtrasi merupakan pembersihan partikel padat dari suatu fluida menggunakan media penyaringan sehingga partikel padat tersebut akan tertahan (Rahayu \& Purnavita, 2008). Suardana (2014) menyatakan bahwa filtrasi dilakukan untuk memisahkan zat padat yang tidak dapat larut dalam zat cair. Materi mengenai filtrasi dipelajari siswa SMP kelas VII mata pelajaran IPA pada KD 3.3 Menjelaskan konsep campuran dan zat tunggal (unsur dan senyawa), sifat fisika dan kimia, perubahan fisika dan kimia dalam kehidupan sehari-hari.

Pembentukan kristal garam terjadi setelah yeh nyah dijemur selama beberapa hari, proses yang terjadi selama pembentukan kristal disebut dengan kristalisasi. Kristalisasi merupakan salah satu contoh pemisahan campuran, Suardana (2014) menyampaikan bahwa kristalisasi dilakukan untuk memisahkan zat padat yang larut dalam zat cair. Materi mengenai kristalisasi dipelajari siswa SMP kelas VII mata pelajaran IPA pada KD 3.3 Menjelaskan konsep campuran dan zat tunggal (unsur dan senyawa), sifat fisika dan kimia, perubahan fisika dan kimia dalam kehidupan sehari-hari.

Kristalisasi terjadi melalui dua tahap, diantaranya adalah nukleasi atau pembentukan inti Kristal dan pertumbuhan kristal, laju nukleasi dan pertumbuhan kristal dipengaruhi oleh supersaturtasi (McCabe dalam Pinalla, 2011). Materi mengenai kristalisasi dipelajari siswa SMP kelas VII mata pelajaran IPA pada KD 3.3 Menjelaskan konsep campuran dan zat tunggal (unsur dan senyawa), sifat fisika dan kimia, perubahan fisika dan kimia dalam kehidupan sehari-hari.

\section{KESIMPULAN}

Simpulan dari penelitian ini adalah proses produksi Garam Amed terdiri atas delapan tahap. Tahap pertama adalah persiapan pesasahan. Kedua adalah penyiraman pesasahan dengan air laut. Ketiga adalah peratan air laut dengan tanah sari. Keempat adalah penyaringan. Kelima adalah penjemuran. Keenam adalah proses pemanenan. Ketujuh adalah penyortiran. Kedelapan adalah pengemasan. Berdasarkan prosesnya, terdapat beberapa penerapan konsep ilmiah di dalamnya. Berdasarkan proses pengolahan data diperoleh kajian etnosains dalam proses produksi Garam Amed yang terdapat pada materi IPA SMP kelas VII dan VIII, diantaranya terdapat pada KD 3.2 Mengklasifikasi makhluk hidup dan benda berdasarkan karakteristik yang diamati, KD 3.6 Menjelaskan berbagai zat aditif dalam makanan dan minuman, zat adiktif, serta dampaknya terhadap kesehatan, KD 3.5 Menganalisis sistem pencernaan manusia dan gangguan yang berhubungan dengan sistem pencernaan, serta upaya menjaga kesehatannya, KD 3.3 Menjelaskan konsep campuran dan zat tunggal (unsur dan senyawa), sifat fisika dan kimia, perubahan fisika dan kimia dalam kehidupan sehari-hari, serta KD 3.4 Menganalisis konsep suhu, pemuaian dan perpindahan kalor, dan penerapannya dalam kehidupan sehari-hari termasuk mekanisme menjaga kestabilan suhu tubuh pada manusia. 


\section{DAFTAR PUSTAKA}

Ariyanti, S. T., (2016). Produksi Garam Indonesia. Dalam: Z. Salim \& E. Munadi, penyunt. Info Komoditi Garam. Jakarta Selatan: Badan Pengkajian dan Pengembangan Perdagangan Kementrian Perdagangan Republik Indonesia berkerja sama dengan Al Mawardi Prima Anggota IKAPI DKI Jaya, Halaman 7-30.

Efendy, M., Muhsoni, F. F., Shidiq, R. F. \& Heryanto, A., (2012). Garam Rakyat Potensi dan Permasalahan. Bangkalan: UTM Press, Universitas Trunojoyo Madura.

Hadi, W. P., (2019). Terasi Madura: Kajian Etnosains dalam Pembelajaran IPA untuk Menumbuhkan Nilai Kearifan Lokal dan Karakter Siswa. Jurnal Inovasi Pendidikan Sains, 10(1), Halaman 4555. http://dx.doi.org/10.20527/quantum.v10i1.5877

Hoiriyah, Y. U., (2019). Peningkatan Kualitas Produksi Garam Menggunakan Teknologi Geomembran. Jurnal Studi Manajemen dan Bisnis (JSMB), 6(2), Halaman 35-42. https://doi.org/10.21107/jsmb.v6i2.6684

Ingot, S. R. \& Lestari, T. K., (2016). Konsumsi Garam. Dalam: Z. Salim \& E. Munadi, penyunt. Info Komoditi Garam. Jakarta Selatan: Badan Pengkajian dan Pengembangan Perdagangan Kementerian Perdagangan Republik Indonesia bekerja sama dengan Al Mawardi Prima Anggota IKAPI DKI Jaya, Halaman 31-47.

Jufrida \& Basuki, F. R., (2019). Pengembangan Buku IPA Berbasis Kearifan Lokal Jambi pada Materi Tekanan serta Getaran dan Gelombang. Indonesian Journal of Science and Mathematics Education, 2(3), Halaman 287-297. https://doi.org/10.24042/ijsme.v2i3.4353

Khilman, N., (2018). Kajian Etnosains Proses Pembuatan Genteng sebagai Bahan Ajar Tambahan Pelajaran IPA Terpadu. Jurnal Penelitian Pembelajaran Fisika, 9(2), Halaman 98-103. https://doi.org/10.26877/jp2f.vgi2.3107

Marihati \& Muryati, (2008). Pemisahan dan Pemanfaatan Bitern sebagai Salah Satu Upaya Peningkatan Pendapatan Petani Garam. Buletin Penelitian dan Pengembangan Industri.

Puspasari, A. et al., (2019). Implementasi Etnosains dalam Pembelajaran IPA di SD Muhammadiyah Alam Surya Mentari Surakarta. Science Education Journal (SEJ), 3(1), Halaman 25-31. Doi: 10.21070/sej.v3i1.2426

Rahayu, S. S. \& Purnavita, S., (2008). Kimia Industri untuk Sekolah Menengah Kejuruan. Jilid 2 penyunt. Jakarta: Direktorat Pembinaan Sekolah Menengah Kejuruan.

Rositawati, A. L., Taslim, C. M. \& Soetrisnanto, D., (2013). Rekristalisasi Garam Rakyat dari Daerah Demak untuk Mencapai SNI Garam Industri. Jurnal Teknologi Kimia dan Industri (JKTI), 2(4), Halaman 217-225.

Suardana, I. N., (2014). Analisis Relevansi Budaya Lokal dengan Materi Kimia SMA untuk Mengembangkan Perangkat Pembelajaran Inkuiri Terbimbing Berbasis Budaya. Jurnal Pendidikan Indonesia, 3(1), Halaman 337-347. http://dx.doi.org/10.23887/jpi-undiksha.v3i1.2916

Sudarmin, (2014). Pendidikan Karakter, Etnosains dan Kearifan Lokal (Konsep dan Penerapannya dalam Penelitian dan Pembelajaran Sains). Edisi 1 penyunt. Semarang: CV. Swadaya Manunggal.

Sugiyono, (2017a). Metode Penelitian Kuantitatif, Kualitatif, dan R\&D. Edisi 1 penyunt. Bandung: Alfabeta.

Sugiyono, (2017b). Metode Penelitian Kualitatif untuk Penelitian yang Bersifat Eksploratif, Enterpretif, Interaktif, dan Konstruktif. Jilid 4 penyunt. Bandung: Alfabeta.

Sumarni, W., (2018). Etnosains dalam Pembelajaran Kimia: Prinsip, Pengembangan, dan Implementasinya. Edisi 1 penyunt. Semarang: UNNES PRESS.

Trianto, (2010). Model Pembelajaran Terpadu Konsep, Strategi dan implementasinya dalam Kurikulum Tingkat Satuan Pendidikan (KTSP). Edisi 2 penyunt. Jakarta: Bumi Aksara. 
Widodo, W., Rachmadiarti, F., Hidayati, S. N., Suryanda, A., Cahyana, U., Kistinah, I., Suryatin, B. (2014). Ilmu Pengetahuan Alam SMP/MTs Kelas VIl. Jakarta: Pusat Kurikulum dan Perbukuan, Balitbang, Kemendikbud.

\section{Ni Luh Putu Oktiyana Rista Ayuni}

Program Studi S1 Pendidikan IPA FMIPA UNDIKSHA, aktif melakukan penelitian pada bidang Pendidikan IPA, dapat dihubungi melalui email: Luhoktiyana16@gmail.com

\section{Nyoman Suardana}

Dosen Program Studi Pendidikan S1 IPA FMIPA UNDIKSHA, aktif melakukan penelitian pada bidang Pendidikan IPA, dapat dihubungi melalui email: inyomansuardana@gmail.com

\section{Luh Mitha Priyanka}

Mahasiswa Program Studi S1 Pendidikan IPA FMIPA UNDIKSHA, aktif melakukan penelitian pada bidang Pendidikan IPA, dapat dihubungi melalui email: luh.mitha@undiksha.ac.id 